\title{
Correction to: Identification of key biomarkers and immune infiltration in systemic lupus erythematosus by integrated bioinformatics analysis
}

\author{
Xingwang Zhao ${ }^{1 \dagger}$, Longlong Zhang ${ }^{3,4 \dagger}$, Juan Wang ${ }^{1}$, Min Zhang ${ }^{1}$, Zhiqiang Song ${ }^{1}$, Bing $\mathrm{Ni}^{2^{*}}$ and Yi You ${ }^{1 *}$ (1)
}

\section{Correction to: J Transl Med (2021) 19:35}

https://doi.org/10.1186/s12967-020-02698-x

Following publication of the original article [1], the authors identified an error in the corresponding authorship. In the original article, Bing $\mathrm{Ni}$ is indicated as the sole corresponding author. However, Bing Ni shares corresponding authorship with Yi You.

The corrected corresponding authorship been updated in the author group above and the original article [1] has been corrected. The publisher apologises to the authors and readers for the inconvenience caused by this error.
Published online: 11 February 2021

\section{Reference}

1. Zhao, et al. Identification of key biomarkers and immune infiltration in systemic lupus erythematosus by integrated bioinformatics analysis. J Transl Med. 2021;19:35. https://doi.org/10.1186/s12967-020-02698-X.

\section{Publisher's Note}

Springer Nature remains neutral with regard to jurisdictional claims in published maps and institutional affiliations.

\section{Author details}

${ }^{1}$ Department of Dermatology, Southwest Hospital, Army Medical University, Third Military Medical University, Chongqing 400038, China. ${ }^{2}$ Department of Pathophysiology, College of High Altitude Military Medicine, Army Medical University, Third Military Medical University, Chongaing, China. ${ }^{3}$ State Key Laboratory of Genetic Resources and Evolution, Kunming Institute of Zoology, Chinese Academy of Sciences, Kunming 650223, China. ${ }^{4}$ Kunming College of Life Science, University of Chinese Academy of Sciences, Kunming 650204, China.

Full list of author information is available at the end of the article

(c) The Author(s) 2021. This article is licensed under a Creative Commons Attribution 4.0 International License, which permits use, sharing, adaptation, distribution and reproduction in any medium or format, as long as you give appropriate credit to the original author(s) and the source, provide a link to the Creative Commons licence, and indicate if changes were made. The images or other third party material in this article are included in the article's Creative Commons licence, unless indicated otherwise in a credit line to the material. If material is not included in the article's Creative Commons licence and your intended use is not permitted by statutory regulation or exceeds the permitted use, you will need to obtain permission directly from the copyright holder. To view a copy of this licence, visit http://creativeco mmons.org/licenses/by/4.0/. The Creative Commons Public Domain Dedication waiver (http://creativecommons.org/publicdomain/ zero/1.0/) applies to the data made available in this article, unless otherwise stated in a credit line to the data. 